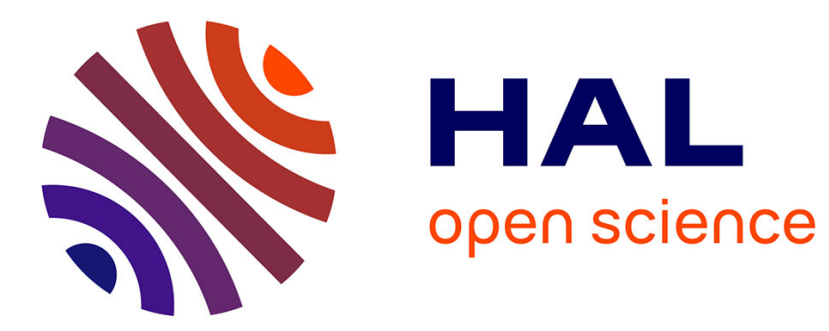

\title{
Performance of a lozenge monopole antenna made of pure composite laminate
}

\author{
Lilia Manac'H, Xavier Castel, Mohamed Himdi
}

\section{To cite this version:}

Lilia Manac'H, Xavier Castel, Mohamed Himdi. Performance of a lozenge monopole antenna made of pure composite laminate. Progress In Electromagnetics Research Letters, 2012, 35, pp.115-123. 10.2528/PIERL12083003 . hal-00743812

\section{HAL Id: hal-00743812 \\ https://hal.science/hal-00743812}

Submitted on 13 May 2014

HAL is a multi-disciplinary open access archive for the deposit and dissemination of scientific research documents, whether they are published or not. The documents may come from teaching and research institutions in France or abroad, or from public or private research centers.
L'archive ouverte pluridisciplinaire HAL, est destinée au dépôt et à la diffusion de documents scientifiques de niveau recherche, publiés ou non, émanant des établissements d'enseignement et de recherche français ou étrangers, des laboratoires publics ou privés. 


\title{
PERFORMANCE OF A LOZENGE MONOPOLE ANTENNA MADE OF PURE COMPOSITE LAMINATE
}

\author{
L. Manac'h", X. Castel, and M. Himdi
}

Institut d'Electronique et de Télécommunications de Rennes, UMR-CNRS 6164, Université de Rennes 1, 18 rue Henri Wallon, 22004 Saint-Brieuc \& Campus de Beaulieu, 263 avenue du Général Leclerc, 35042 Rennes, France

E-mails: lilia.manach@univ-rennes1.fr; xavier.castel@univ-rennes1.fr;

mohamed.himdi@univ-rennes1.fr

\begin{abstract}
The use of carbon-fiber tissue as a replacement for metal radiating element has been investigated to fabricate microwave antennas embedded in composite material panels. A single ply of a dry carbon-fiber tissue with a $0.15 \Omega / \mathrm{sq}$ sheet resistance value and a square shape $(50 \mathrm{~mm} \times 50 \mathrm{~mm})$ acts as the radiating element. It has been embedded inside the glass-fiber and polyester resin composite laminate by using the infusion technique. The measured radiofrequency characteristics of the pure composite antenna are presented, discussed and compared to those of a reference counterpart, made from a plain metal sheet. The pure composite antenna exhibits a measured gain strictly alike to that of the reference antenna up to $2.1 \mathrm{GHz}$.
\end{abstract}

Keywords - Composite materials; Carbon; Monopole antennas; Antenna measurements

\section{INTRODUCTION}

Metals (copper, aluminum,...) are commonly used as radiating elements of antennas. Nevertheless, the cost, the fabrication procedure, the weight or the corrosion resistance can limit their applications. Recent studies have presented various conductive composite materials as a replacement for metals [1-3]. A patch antenna has been fabricated from a conducting-polymer in [1], or from a textile coated with carbon nanotubes (CNTs) and gold in [2]. Inkjet printing can be applied to make high conductive material for planar antenna applications [3]. Theoretical results of a Bow-Tie antenna obtained by numerical simulations and designed with braided-tissue of carbon-fibers or reinforced long carbon-fibers have been presented for RFID systems in [4]. A wire monopole antenna made of 16 plies of carbon-fiber reinforced polymer has been fabricated and characterized in [5]. At the same time, conductive composite panels can act as 
ground plane for radiating structures (the carbon-fiber reinforced polymer has been investigated in [6,7]), or for electromagnetic shielding in view of electromagnetic compatibility applications $[8,9]$.

In recent years, structurally integrated antennas are growing of interest, as the attachment of conventional antennas at the surface of composite panels impacts their structural integrity. For example, smart-skin phased array antenna systems made out of honeycomb sandwich structure have been developed specially in [10] for aircraft applications.

In this letter, we investigate the design and the fabrication of a pure composite antenna using a single square carbon-fiber tissue as the radiating element. For this purpose, a simple shape, namely a planar lozenge monopole antenna, has been studied. In the first part, the carbon-fiber tissue and the composite laminate are characterized. Then, the antenna design and the fabrication process are described. Last, the experimental results such as input impedance, Voltage Standing Wave Ratio (VSWR), radiation pattern, gain and efficiency of the pure composite antenna are compared with those of a reference counterpart (for which the radiating element is a plain copper sheet) at microwaves.

\section{COMPOSITE MATERIAL CHARACTERISTICS}

Carbon-fiber tissues are commonly used in the field of advanced composites engineering, mainly for their mechanical properties (high strength and light-weight). However, their use for microwave applications remains fairly low [4-10]. In this section, we present the electrical characterization of a dry carbon-fiber tissue in view of antenna application. The dielectric characterization of the composite panel, in which the carbon radiating element is embedded, is also detailed.

\subsection{Electrical properties of the dry carbon-fiber tissue}

Electrical characteristics of the carbon-fiber tissues depend on, (i) the quality of the carbon filaments, (ii) the number of carbon filaments per fiber or strand (value of $K$, with $1 K$ is 1000 filaments), (iii) the weave of the tissue. We select for this study a 2/2 woven tissue with 12000 filaments $(12 K)$ and a grammage of $385 \mathrm{~g} / \mathrm{m}^{2}$. These specifications ensure strong mechanical and valuable electrical properties. $D C$ electrical characteristics of the carbon-fiber tissue and of the copper sheet (which stands as the reference) are provided in Table 1. Sheet resistances $R_{s}$ have been checked with a 4-probe set-up.

As expected, the sheet resistance of the carbon-fiber tissue is larger than that of the copper sheet. But its value remains satisfactory (lower than $1 \Omega / \mathrm{sq}$ ) in view of microwave applications. Electrical conductivity $\sigma_{D C}$ of both samples 
has been computed from the formula relating $R_{S}, \sigma_{D C}$ and the thickness $t$ of the sheet under test $\left(R_{s}=1 / \sigma_{D C} t\right)$.

Table 1. Electrical characteristics of the carbon-fiber tissue and the copper sheet at room temperature.

\begin{tabular}{|c|c|c|}
\hline Measured values & $\begin{array}{c}\text { Dry carbon-fiber } \\
\text { tissue }\end{array}$ & Copper sheet \\
\hline Thickness $t$ & $370 \mu \mathrm{m}$ & $68 \mu \mathrm{m}$ \\
\hline Sheet resistance $R_{S}$ & $0.15 \Omega / \mathrm{sq}$ & $2.5 \times 10^{-4} \Omega / \mathrm{sq}$ \\
\hline $\begin{array}{c}\text { Electrical } \\
\text { conductivity } \sigma_{D C}\end{array}$ & $18 \times 10^{3} \mathrm{~S} / \mathrm{m}$ & $5.9 \times 10^{7} \mathrm{~S} / \mathrm{m}$ \\
\hline
\end{tabular}

It is worth noting that qualitative $A C$ electrical characteristics and conductivity values at microwaves of carbon-fiber reinforced polymers are accessible through other methods $[5-6,11]$. The value of the conductivity measured in $D C$ mode $\left(\sigma_{D C}=18 \times 10^{3} \mathrm{~S} / \mathrm{m}\right)$ is consistent with the values provided in $A C$ mode in the literature: $\sigma_{A C}=51 \times 10^{3} \mathrm{~S} / \mathrm{m}$ at $980 \mathrm{MHz}$ in [5] and $\sigma_{A C}=$ $10 \times 10^{3} \mathrm{~S} / \mathrm{m}$ at $8 \mathrm{GHz}$ in [6]. For reference, the conductivity of pure graphite is $\sigma_{\text {graphite }}=1.2 \times 10^{5} \mathrm{~S} / \mathrm{m}[5,11]$.

\subsection{Dielectric properties of the composite material}

The dielectric characteristics of the composite laminate (E-glass-fiber tissues infused with polyester resin) have been performed by the stub perturbation technique [12]. The relative permittivity $\left(\varepsilon_{r}\right)$ and the loss tangent (tan $\delta$ ) are respectively equal to 4.5 and 0.01 at $1 \mathrm{GHz}$. These data are required to design the antenna.

\section{ANTENNA DESIGN AND FABRICATION}

\subsection{Antenna design}

The design is a single lozenge monopole antenna [13] with a radiating square element $(50 \mathrm{~mm} \times 50 \mathrm{~mm}$, Figures $1 \mathrm{a}$ and $1 \mathrm{~b})$ embedded in the composite laminate characterized in the previous section. To get close to the printed antenna technology, one single ply of the dry carbon-fiber tissue and one sheet of copper have been used for the pure composite antenna and the reference counterpart, respectively. Hence the ohmic resistance of the radiating element is equal to $R_{s}$. 


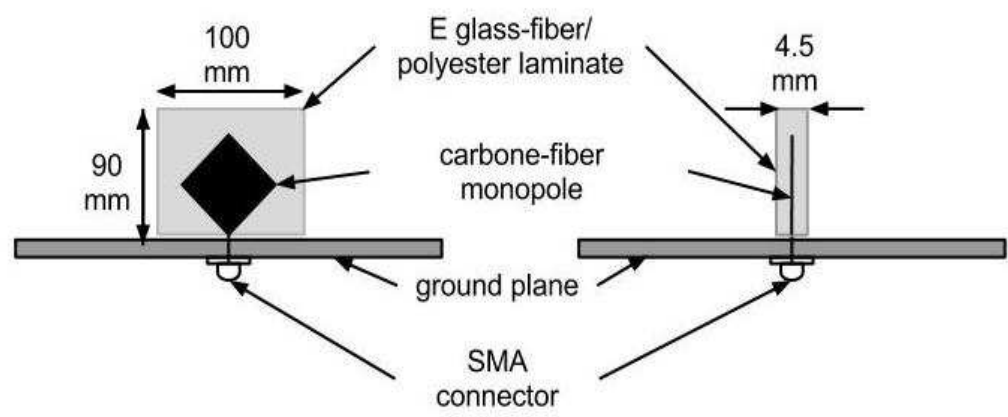

(a)

(b)

Figure 1. Lozenge monopole antenna: (a) front-view; (b) side-view.

\subsection{Fabrication process}

The two planar lozenge monopole antennas (carbon-fiber and copper counterpart) have been fabricated by the infusion process. The radiating element is cut to the required size in the dry carbon-fiber tissue and in the copper sheet, respectively. Four plies of E-glass-fiber tissue are placed on both sides of the radiating element and infused under vacuum with a liquid polyester resin (with $2 \%$ by weight of catalyst). The polymerization reaction is complete after 4 hours at room temperature and the samples are then suitable for release without postbake (Figures $2 \mathrm{a}$ and $2 \mathrm{~b}$ ).

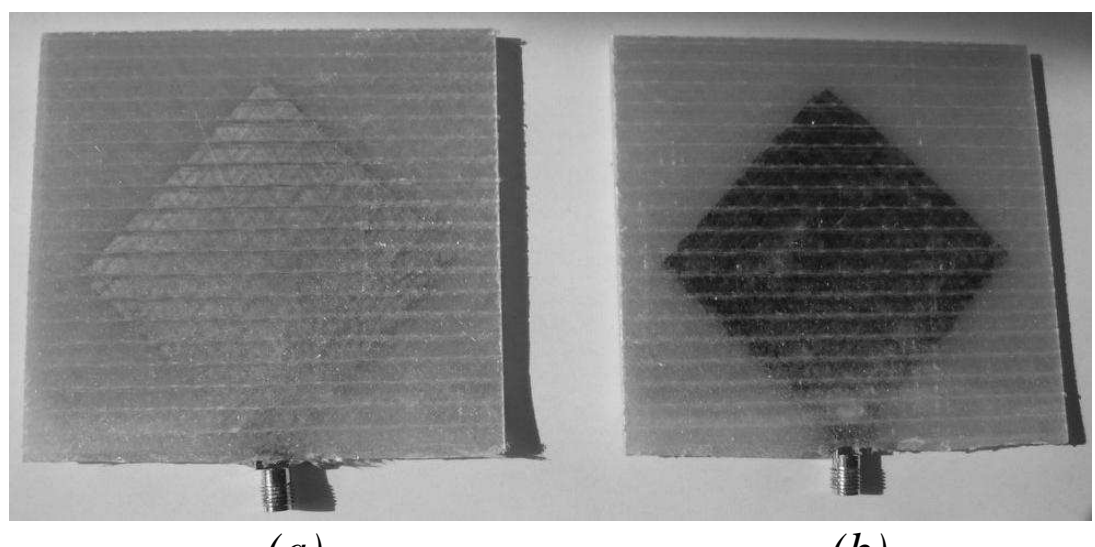

(a)

(b)

Figure 2. Pictures of the lozenge monopole antennas: (a) Copper radiating element embedded inside composite laminate (reference antenna); (b) Carbonfiber radiating element (one ply) embedded inside composite laminate. 


\section{MICROWAVE PERFORMANCE}

The input impedance, Voltage Standing Wave Ratio (VSWR), radiation pattern, gain and efficiency of both antennas have been measured or computed, compared and discussed.

Antennas are placed perpendicularly above a square metal ground plane $(300 \mathrm{~mm} \times 300 \mathrm{~mm}$ ) and fed at the corner through a SMA connector (Figures 1a and 1b). Microwave measurements are performed in a SATIMO SG32 anechoic chamber. The near-field chamber is equipped with a network of 31 bipolarized receiving antennas placed on an arch (circle-shaped arrangement) with a $1.5 \mathrm{~m}$ internal-diameter. Each receiving antenna is a cross-shaped sensor sensitive to two orthogonal polarizations of the tangential radiated electromagnetic field. The operating frequency ranges from $600 \mathrm{MHz}$ to $6 \mathrm{GHz}$. The integration of the radiation pattern provides the directivity of the antenna under test. The ratio of gain to directivity gives the antenna efficiency.

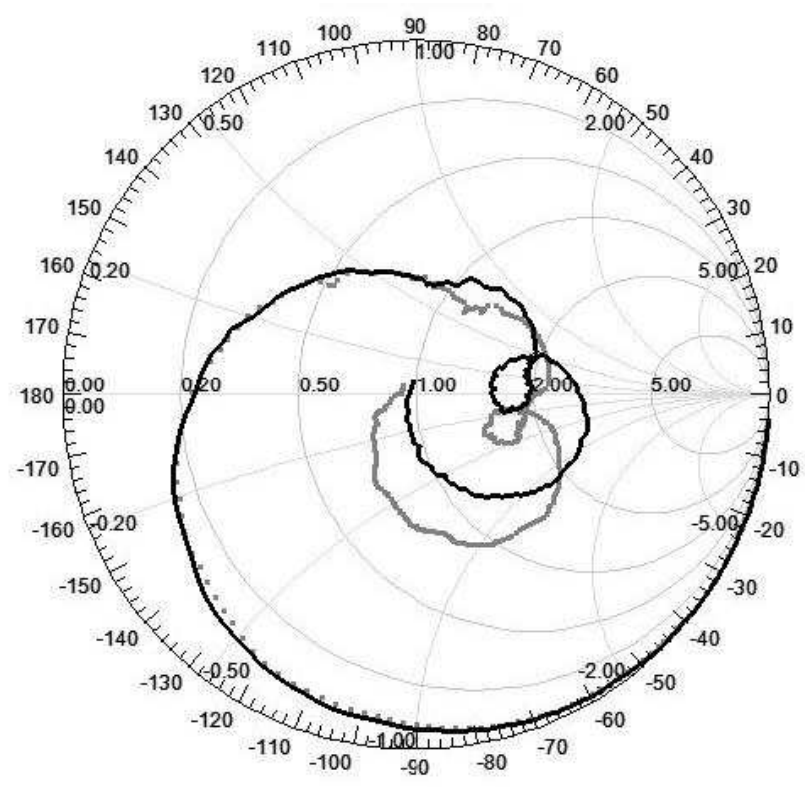

Figure 3. Measured input impedances (from $25 \mathrm{MHz}$ to $3 \mathrm{GHz}$ ) of the carbonfiber monopole antenna (grey dotted line) and of the copper counterpart (black solid line). 


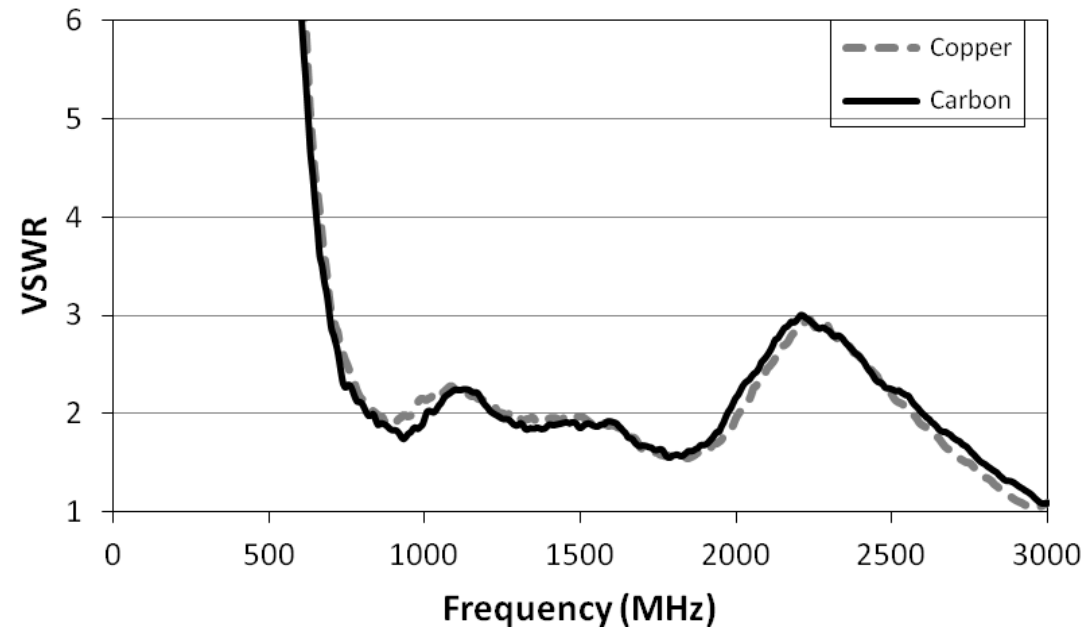

Figure 4. Measured Voltage Standing Wave Ratios (VSWR) (from $25 \mathrm{MHz}$ to $3 \mathrm{GHz}$ ) of the carbon-fiber monopole antenna (grey dashed line) and of the copper counterpart (black solid line).

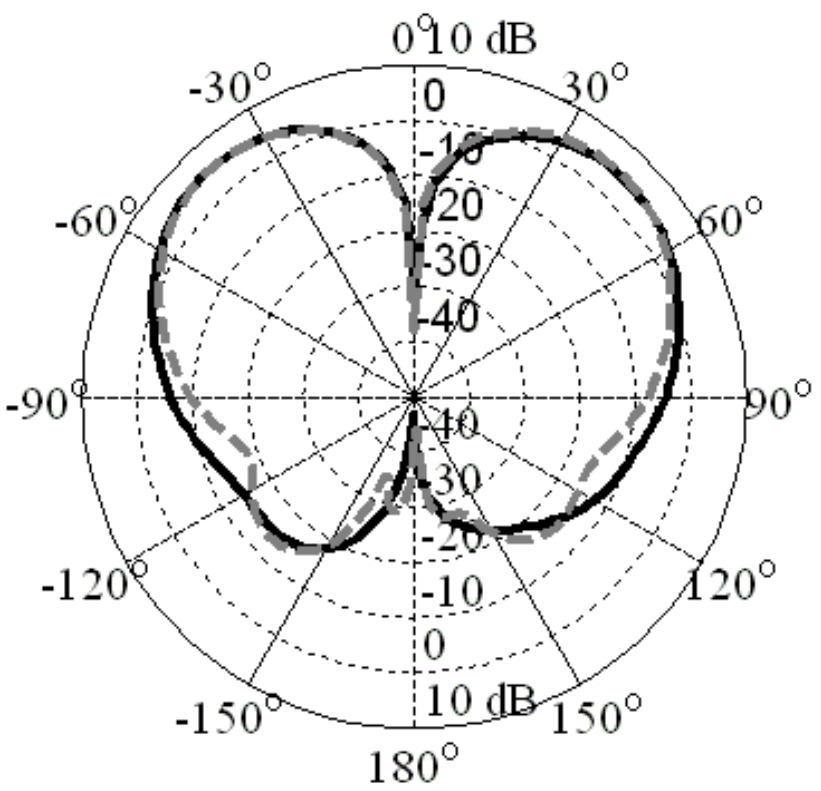

Figure 5. Measured radiation patterns in E-plane at $2.1 \mathrm{GHz}$ of the carbonfiber monopole antenna (grey dashed line) and of the copper counterpart (black solid line). 


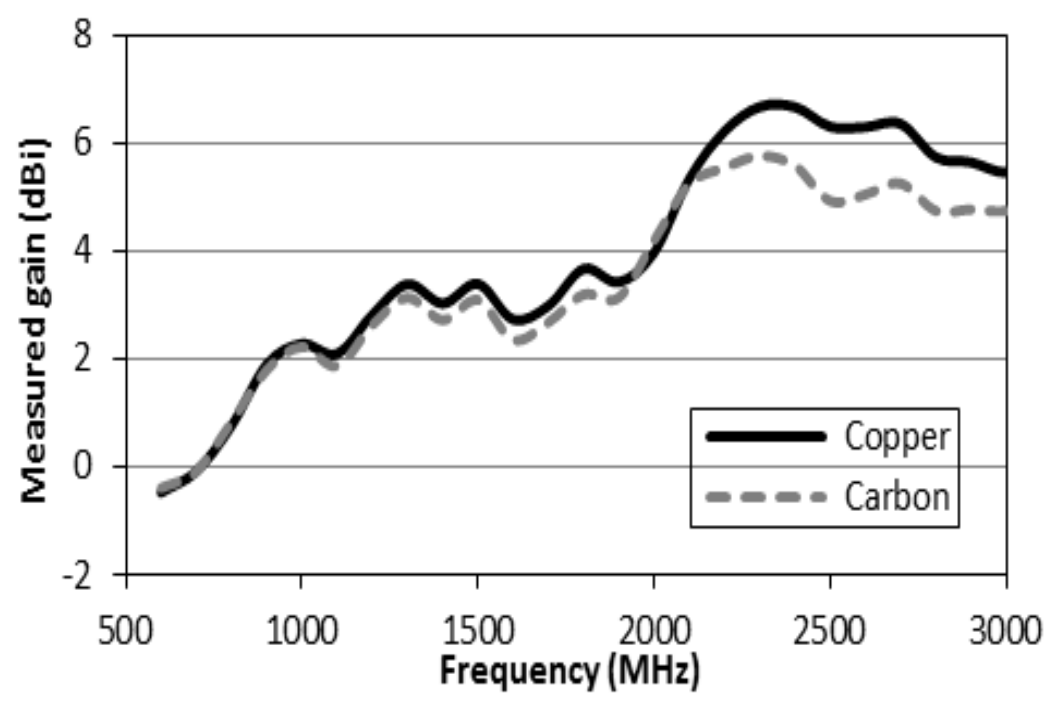

Figure 6. Maximum measured gains (from $600 \mathrm{MHz}$ to $3 \mathrm{GHz}$ ) of the carbonfiber monopole antenna (grey dashed line) and of the copper counterpart (black solid line).

Below 2.1 GHz, the input impedance and the VSWR of both antennas are alike. The corresponding curves overlap, as seen in Figure 3 and Figure 4. Note that both VSWRs remain lower than 3 starting from $700 \mathrm{MHz}$. The input impedances match a value close to $11 \Omega$ at the first resonance: $610 \mathrm{MHz}$ for the carbon-fiber monopole antenna and $640 \mathrm{MHz}$ for the copper counterpart. The slight difference comes from the material conductivity and the thickness of the respective radiating elements (Table 1). The measured radiation patterns of the carbon-fiber monopole antenna and the reference counterpart also overlap well (Figure 5). As expected, they are similar to that of a conventional monopole antenna mounted on a finite ground plane reflector. The maximum measured gains of both antennas are also very close (Figure 6). The larger value of the carbon sheet resistance has then a weak effect at lower frequencies. It is worth noting that the computed skin depths of the carbon-fiber and of the copper sheet antennas are equal to $153.1 \mu \mathrm{m}$ and $2.7 \mu \mathrm{m}$ at $600 \mathrm{MHz}$, respectively. These computed values also confirm the lack of loss due to the skin depth effect.

Above $2.1 \mathrm{GHz}$, the input impedance of the pure composite antenna shows a capacitive effect compared with that of the copper antenna. This behavior, comes from the difference of thickness of the conductive elements (Table 1). A difference on gain values $(\sim 1 \mathrm{dBi})$ is checked. At higher frequencies, the carbon material becomes lossy. Nevertheless, the pure composite antenna provides a maximum measured gain of $5.7 \mathrm{dBi}$ at $2.3 \mathrm{GHz}(6.7 \mathrm{dBi}$ for the reference counterpart). The gains tend towards typical values of a conventional monopole antenna mounted on a finite ground plane reflector $(300 \mathrm{~mm} \times 300 \mathrm{~mm})$, then 
responsible of back radiations (as seen in Figure 5). The low values are also explained by the level of input impedances which leads to match loss. To complete these results, we underline that the mean radiation efficiency between $1 \mathrm{GHz}$ and $2 \mathrm{GHz}$ is close to $85 \%$ for the pure composite antenna, and reaches $90 \%$ for the reference counterpart. Above, it reaches $70 \%$ and $80 \%$, respectively. These data confirm the relevance of the carbon-fiber tissue acting as a radiating element for antenna applications at microwaves.

\section{CONCLUSION}

The use of carbon-fiber tissue as a radiating element for microwave antennas has been investigated. For this purpose, a planar lozenge carbon-fiber radiating element embedded inside a composite laminate has been considered. The radiofrequency performance of the pure composite antenna has been compared up to $3 \mathrm{GHz}$ with that of a reference antenna (using a plain metal sheet as the radiating element). Both samples have been fabricated by the infusion technique. Measurements of input impedances, VSWRs, gains and efficiencies demonstrate the relevance of the carbon-fiber tissue acting for antenna applications in $L$ and $S$ bands.

Besides, the carbon-fiber tissue ensures the strong impregnation of the resin in order to produce a solid composite laminate while metal sheet acts as a default and weakening it mechanically. This pure composite antenna makes it usable for a lot of applications where light-weight, corrosion resistance, smart skins and low profile antennas are needed, such as planar antennas integrated in aircraft wings.

\section{ACKNOWLEDGMENT}

This work has been supported by the FUI'09 SAMCOM project. The authors acknowledge Jérôme Sol from IETR/INSA de Rennes (France) and Nicolas Malandain from ID COMPOSITE/Saint-Brieuc (France) for their technical supports.

\section{REFERENCES}

1. Rmili, H., J.-L. Miane, H. Zangar, and T. Olinga, "Design of microstripfed proximity-coupled conducting-polymer patch antenna," Microwave and Optical Technology Letters, Vol. 48, No. 4, 655-660, 2006.

2. Bayram, Y., Y. Zhou, J.L. Volakis, B.-S. Shim, and N.A. Kotov, "Conductive textiles and polymer-ceramic composites for novel load bearing antennas," Proceedings of Antennas and Propagation Society International Symposium, 1-4, San-Diego, USA, July 2008. 
3. Yang, L., A. Rida, R. Vyas, and M.M. Tentzeris, "RFID tag and RF structures on a paper substrate using inkjet-printing technology," IEEE Transactions on Microwave Theory and Techniques, Vol. 55, No. 12, 2894-2901, 2007.

4. Mehdipour, A., C.W. Trueman, A.R. Sebak, and S.V. Hoa, "Carbon-fiber composite T-Match folded Bow-Tie antenna for RFID applications," Proceedings of Antennas and Propagation Society International Symposium, 1-4, Charleston, USA, June 2009.

5. Galehdar, A., P.J. Callus, and K. Ghorbani, "A novel method of conductivity measurements for carbon-fiber monopole antenna," IEEE Transactions on Antennas and Propagation, Vol.59, No. 6, 2120-2126, 2011.

6. Galehdar, A., W.S.T. Rowe, and K. Ghorbani, "The effect of ply orientation on the performance of antennas in or on carbon fiber composites," Progress in Electromagnetics Research, Vol.116, 123-136, 2011.

7. Seidel, T.J., A. Galehdar, W.S.T. Rowe, S. John, P.J. Callus, and K. Ghorbani, "The anisotropic conductivity of unidirectional carbon fibre reinforced polymer laminates and its effect on microstrip antennas," Proceedings of Asia-Pacific Microwave Conference, 1470-1473, Yokohama, Japan, December 2010.

8. Sarto, M.S., "Hybrid MFIE/FDTD analysis of the shielding effectiveness of a composite enclosure excited by a transient plane wave," IEEE Transactions on Magnetics, Vol. 36, No. 4, 946-950, 2000.

9. Holloway, C.L., M.S. Sarto, and M. Johansson, "Analyzing carbon-fiber composite materials with equivalent-layer models," IEEE Transactions on Electromagnetic Compatibility, Vol. 47, No. 4, 833-844, 2005.

10. Son, S.H., S.Y. Eom, and W. Hwang, "Developement of a smart-skin phased array system with a honeycomb sandwich microstrip antenna," Smart Materials and Structures, Vol. 17, No. 3, 035012, 2008.

11. Galehdar, A., K.J. Nicholson, W.S.T. Rowe, and K. Ghorbani, "The conductivity of unidirectional and quasi isotropic carbon fiber composites," Proceedings of European Microwave Conference, 882-885, Paris, France, September 2010.

12. Liu, D., U. Pfeiffer, J. Gizyb, and B. Gaucher, "Advanced millimeterwave technologies," Wiley Ed., Chap. 5, 163-170, 2009.

13. Hautcoeur, J., F. Colombel, X. Castel, M. Himdi, and E. Motta Cruz, "Optically transparent monopole antenna with high radiation efficiency manufactured with silver grid layer (AgGL),' Electronics Letters, Vol. 45, No. 20, 1014-1016, 2009. 